\title{
Comparative Analisys of Factors Non-Performing Loan in Ukraine and India
}

\author{
Hanna Strokovych ${ }^{1}$, Amit Kumar ${ }^{2}$, Nataliia Pohorelenko ${ }^{3}$, \\ Oleksiy Dzenis ${ }^{1}$, Viktoriia Dzenis ${ }^{1}$
}

\author{
${ }^{1}$ Simon Kuznets Kharkiv National University of Economic, ave. Nauki, 9-A, Kharkiv, 61166, Ukraine \\ ${ }^{2}$ Integral University, Lucknow, U.P., Dasauli, Bas-ha Kursi Road, Lucknow, 226026, India \\ ${ }^{3}$ Scientific Institute of the State High Educational Institution "University of Banking", ave. Peremohy 55, \\ Kharkiv, 61174, Ukraine
}

\begin{abstract}
The article is devoted to theoretical and methodological problems of bank unrecovered loan in Ukraine and India. The purpose of this article is to identify the key sensitive indicators of unrecovered loan in Ukraine and Indian banking system. The article solves the following research tasks: a descriptive statistical analysis of bank unrecovered loan to the total loans, bank cash reserves to the ratio of bank assets, inflation, consumer prices, interest rates on loans, GDP; data on bank bad loans to the total amount of total loans, bank cash reserves, the ratio of bank assets, inflation, consumer prices, interest rates on loans, GDP are standardized; a regression model of the dependence of non-performing bank loans on the total loan on the factors of the ratio of bank cash reserves to bank assets, inflation, consumer prices, interest rates on loans and GDP was built; analysis of the remains of the regression model. According to the results of the study, the main factors that affect bank unrecovered loan for the total amount of loans are: for Ukraine - the ratio of cash reserves to bank assets and GDP; for India - consumer price inflation and GDP.
\end{abstract}

Keywords - unrecovered loan, economic, stability, indicator, banking system, Ukraine, India, cash reserves, bank assets, ratio, inflation, consumer prices, lending interest rate, GDP.

DOI: 10.18421/TEM94-28

https://doi.org/10.18421/TEM94-28

Corresponding author: Hanna Strokovych,

Simon Kuznets Kharkiv National University of Economic, Ukraine.

Email: annastrokovych@gmail.com

Received: 25 July 2020.

Revised: 26 October 2020.

Accepted: 31 October 2020.

Published: 27 November 2020.

(c) BY-NC-ND (C) 2020 Hanna Strokovych et al; published by UIKTEN. This work is licensed under the Creative Commons Attribution-NonCommercial-NoDerivs 4.0 License.

The article is published with Open Access at www.temjournal.com

\section{Introduction}

The banking system ensures the implementation of all processes of accumulation, redistribution of both external and internal financial resources. In fact, it remains the main financial intermediary in the context of globalization. Therefore, ensuring the smooth operation of the banking system is essential for the effective operation of global business. Vertical and horizontal integration of the banking sector is being carried out, which allows attracting a greater amount of financial resources, offering customers a large list of various services, and creating a network of branches around the world.

At the same time, the problem of accumulation of unrecovered loan remains very serious and negatively affects the work of the banking system. It will become especially aggravated during the quarantine and post-quarantine periods, as according to some estimates the world economy will reach the level of 2008 and even worse. Therefore, banks will be forced to adapt in order to ensure efficient operation in the new conditions. Therefore, it is important to identify key sensitive indicators of unrecovered loan. The analysis is carried out on the example of banking systems of Ukraine and India.

The purpose of this article is to identify the key sensitive indicators of unrecovered loan in Ukraine and Indian banking system.

Based on the goal, the article solves the following research tasks:

- a descriptive statistical analysis of bank unrecovered loan to the total loans, bank cash reserves to the ratio of bank assets, inflation, consumer prices, interest rates on loans, GDP;

- data on bank bad loans to the total amount of total loans, bank cash reserves, the ratio of bank assets, inflation, consumer prices, interest rates on loans, GDP are standardized;

- a regression model of the dependence of nonperforming bank loans on the total loan on the factors of the ratio of bank cash reserves to bank assets, inflation, consumer prices, interest rates on loans and GDP was built;

- analysis of the remains of the regression model. 
The basis of the study was scientific papers on unrecovered loan in the banking system and statistical data. To achieve the goal, the following methods were used: abstract-logical method, method of analysis and synthesis - formation and substantiation of the system of indicators of evaluation of unrecovered loan in Ukraine and India banking system; regression analysis - for form a model of dependency bank unrecovered loans to total loans from factors of bank cash reserves to bank assets ratio, inflation, consumer prices, lending interest rate and GDP.

\section{Literature Review}

The problem of unrecovered loan is due to many factors. İslamoğlu examines the effect of macroeconomic variables on the unrecovered loans of various banks of Istanbul and finds the relationship between stock/GDP ratio and commercial loan rates [7]. Author finally conclude that increase in the public borrowing requirements would cause to decrease in loanable funds in loan market and therefore bank are obliged to limit their loan placement.

Slavyuk, Shkvarchuk, Kondrat focus on the main reason for the financial market [11]. The imbalance in Ukraine lies in the fact that financial intermediaries do not fulfill their functions of turning savings into real investments. They prove that their main activity is speculative and involves a high level of risk and does not affect the GDP of Ukraine.

Beck, Jakubik, and Piloiu indicate a continued downward trend in global economic activity, which is the most important risk for the quality of banking assets [2]. In particular, a depreciation of the exchange rate can lead to an increase in unrecovered loan in districts that have a high degree of leadership in foreign currency with respect to unhedged borrowers.

Korpaniuk analyses the accounting of nonperforming long-term bank loan in Ukraine [7], [9]. According to her the banking system of the country, trends in the development of methodical support of the given process. It has been found that the present situation, the use of European experience in this field is important, she finally concludes the accounting of unrecovered loan obtained by using updated accounting method analysis.
According to Mohanty, Das, Kumar, corporate variables, such as net sales growth and net profit margin, have a statistically negative effect on gross arrears ratio [8], [10]. This implies that higher rates of economic growth, an increase in the stock market index and improved performance in the private corporate sector will lead to a decrease in the gross arrears ratio, so that as a result of a bank scan, more loans will be provided to meet the demand for credit in the economy. The authors argue that capital injection is one of the factors that delay the problem of unrecovered loan.

Research Altunbas et al. [1] indicate that unrecovered loan lead to inefficient financing in the banking sector. Berger and De Yung [3] note that poor governance in banking institutions leads to poor quality loans and, consequently, increases the level of unrecovered loan.

The results of the Nkusu [9] study showed that adverse macroeconomic development, in particular, a decline in real GDP, high unemployment, high interest rates, falling housing prices and falling stock prices negatively affected bad loans.

A study by De Bock and Demyanets [4], [5] showed that a reduction in real GDP, depreciation of the currency against the US dollar, weaker trading conditions and outflow of debt - which leads to an increase in capital, leads to an increase in the aggregate coefficient of overdue debt in the banking sector.

Kjosevski and Petkovski [6], [8] used ROA and ROE as measures of effectiveness for the banks. These indicators are based on net profit, loan impairment costs have been deducted from the operating income. The profitability indicator includes part of the impact arising from increased credit risk. Thus, the author recommends inputting the limitation and offers to researchers use other profitability measures.

\section{Research Results}

Unrecovered loan have been a huge issue to provide economic stability and constantly growth of economies. In Ukraine, unrecovered loan had maximized value to total loans in 2017, 2018, due to influence external and internal factors. As a result, minimum non-performing loan was in 2008 (Table 1). In India, unrecovered loan had maximized value to total total loans in 2017 and the minimum unrecovered loans were in 2008-2010 (Table 2). 
Table 1. Unrecovered loan in the Ukraine Banking System and other indicators

\begin{tabular}{|l|c|c|c|c|c|c|c|c|c|c|c|}
\hline \multicolumn{1}{|c|}{ Indicator Name } & 2008 & 2009 & 2010 & 2011 & 2012 & 2013 & 2014 & 2015 & 2016 & 2017 & 2018 \\
\hline $\begin{array}{l}\text { Bank unrecovered loans to total total } \\
\text { loans (\%) }\end{array}$ & 3,88 & 13,70 & 15,27 & 14,73 & 16,54 & 12,89 & 18,98 & 28,03 & 30,47 & 54,54 & 52,85 \\
\hline $\begin{array}{l}\text { Bank cash reserves to bank assets ratio } \\
(\%)\end{array}$ & 4,23 & 4,95 & 6,30 & 5,81 & 5,49 & 7,01 & 5,77 & 11,66 & 11,36 & 11,16 & 10,74 \\
\hline Inflation of consumer prices (annual \%) & 25,23 & 15,88 & 9,37 & 7,96 & 0,57 & $-0,24$ & 12,07 & 48,70 & 13,91 & 14,44 & 10,95 \\
\hline Lending interest rate (\%) & 17,49 & 20,86 & 15,87 & 15,95 & 18,39 & 16,65 & 17,72 & 21,82 & 19,24 & 16,38 & 19,00 \\
\hline GDP (mln US\$) & 179992 & 117228 & 136419 & 163160 & 175781 & 183310 & 131805 & 90615 & 93270 & 112154 & 130832 \\
\hline
\end{tabular}

Source: World Bank Group.

Table 2. Unrecovered loan in the India Banking System and other indicators

\begin{tabular}{|l|c|c|c|c|c|c|c|c|c|c|c|}
\hline \multicolumn{1}{|c|}{ Indicator Name } & 2008 & 2009 & 2010 & 2011 & 2012 & 2013 & 2014 & 2015 & 2016 & 2017 & 2018 \\
\hline $\begin{array}{l}\text { Bank unrecovered } \\
\text { loans to total total } \\
\text { loans (\%) }\end{array}$ & 2,45 & 2,45 & 2,45 & 2,67 & 3,37 & 4,03 & 4,35 & 5,88 & 9,19 & 9,98 & 9,46 \\
\hline $\begin{array}{l}\text { Bank cash reserves to } \\
\text { bank assets ratio (\%) }\end{array}$ & 11,26 & 10,00 & 9,80 & 9,15 & 8,79 & 8,12 & 8,54 & 8,47 & 10,23 & 8,19 & 8,12 \\
\hline $\begin{array}{l}\text { Inflation of consumer } \\
\text { prices (annual \%) }\end{array}$ & 8,349 & 10,882 & 11,989 & 8,858 & 9,312 & 10,908 & 6,353 & 5,872 & 4,941 & 2,491 & 4,861 \\
\hline $\begin{array}{l}\text { Lending interest rate } \\
\text { \%) }\end{array}$ & 13,31 & 12,19 & 8,33 & 10,17 & 10,6 & 10,29 & 10,25 & 10,01 & 9,67 & 9,51 & 9,40 \\
\hline GDP (mlrd US\$) & 1198,9 & 1341,89 & 1675,62 & 1823,05 & 1827,64 & 1856,72 & 2039,13 & 2103,59 & 2290,43 & 2652,24 & 2718,73 \\
\hline
\end{tabular}

Source: World Bank Group

The data for this study was analyzed over the period 2008 to 2018 . Table 3, 4 presents a summary statistics of bank unrecovered loans to total loans, bank cash reserves to bank assets ratio, inflation, consumer prices, lending interest rate and GDP over the period 2008 to 2018 .

Table 3. Descriptive statistics for Ukraine

\begin{tabular}{|l|c|c|c|c|c|}
\hline \multicolumn{1}{|c|}{ Indicator Name } & Valid N & Mean & Minimum & Maximum & Std. Dev. \\
\hline Bank unrecovered loans to total total loans (\%) & 11 & 23,8 & 3,88 & 54,5 & 16,43 \\
\hline Bank cash reserves to bank assets ratio (\%) & 11 & 7,7 & 4,23 & 11,7 & 2,91 \\
\hline Inflation of consumer prices (annual \%) & 11 & 14,4 & $-0,24$ & 48,7 & 13,36 \\
\hline Lending interest rate (\%) & 11 & 18,1 & 15,87 & 21,8 & 1,97 \\
\hline GDP (mln US\$ ) & 11 & 137687,8 & 90615,00 & 183310,0 & 33635,61 \\
\hline
\end{tabular}

Source: development of authors

We can analyze the information presented in Table 3 about Ukraine. The average bank unrecovered loans to total total loans size is $23,8 \%$ with a maximum size of $54,54 \%$ in 2017 and a minimum size of $3,88 \%$ in 2008. Standard deviation is 16,43 . Bank cash reserves to bank assets ratio size is $7,7 \%$ with a maximum size of $11,7 \%$ in 2015 and a minimum size of $4,23 \%$ in 2008. Standard deviation is 2,91 . Inflation, consumer prices size is $14,4 \%$ with a maximum size of $48,7 \%$ in 2015 and a minimum size of $-0,24 \%$ in 2013. Standard deviation is 13,36 . Lending interest rate size is $18,1 \%$ with a maximum size of $21,82 \%$ in 2015 and a minimum size of 15,87 $\%$ in 2010 . Standard deviation is 1,97 . GDP size is 137687,8 mln US\$ with a maximum size of 183310 mln US\$ in 2013 and a minimum size of 90615,00 mln US\$ in 2015. Standard deviation is 33635,61. 
Table 4. Descriptive Statistics for India

\begin{tabular}{|l|c|c|c|c|c|}
\hline \multicolumn{1}{|c|}{ Indicator Name } & Valid N & Mean & Minimum & Maximum & Std. Dev. \\
\hline Bank unrecovered loans to total total loans (\%) & 11 & 5,116 & 2,450 & 9,980 & 3,0304 \\
\hline Bank cash reserves to bank assets ratio (\%) & 11 & 9,152 & 8,120 & 11,260 & 1,0378 \\
\hline Inflation of consumer prices (annual \%) & 11 & 7,711 & 2,491 & 11,989 & 3,0188 \\
\hline Lending interest rate (\%) & 11 & 10,339 & 8,330 & 13,310 & 1,3609 \\
\hline GDP (mlrd US\$) & 11 & 1957,085 & 1198,900 & 2718,730 & 477,4918 \\
\hline
\end{tabular}

Source: development of authors

Then we can analyze the information presented in Table 4 about India. The average bank unrecovered loans to total loans size is $5,116 \%$ with a maximum size of $9,98 \%$ in 2017 and a minimum size of $2,45 \%$ in 2008-2010. Standard deviation is 3,0304. Bank cash reserves to bank assets ratio size is $9,152 \%$ with a maximum size of $11,26 \%$ in 2008 and a minimum size of $8,12 \%$ in 2013. Standard deviation is 1,0378 . Inflation, consumer prices size is $7,711 \%$ with a maximum size of $11,989 \%$ in 2010 and a minimum size of $2,481 \%$ in 2017. Standard deviation is 3,0188 . Lending interest rate size is $10,339 \%$ with a maximum size of $13,310 \%$ in 2008 and a minimum size of $8,33 \%$ in 2010 . Standard deviation is 1,3609 . GDP size is 1957,085 mlrd US\$ with a maximum size of 2718,730 mlrd US\$ in 2018 and a minimum size of 1198,900 mlrd US\$ in 2008. Standard deviation is 477,4918 .

Thus, unrecovered loan adversely affect economic stability and economic growth. The statistical analysis carried out indicates more significant deviations in the analyzed indicators in the banking system of Ukraine compared with India. The gradual growth of unrecovered loan in Ukraine, their increase by 13.62 times leads to deflation, and after that - to sharp inflationary processes and an increase in interest rates on loans. This impedes the development of the economy. In India, we observe a gradual increase in unrecovered loan and their increase by 3.87 times over 11 years, which is characterized by slight inflationary fluctuations and lower lending rates. This allows the development of the Indian economy.
Therefore, it seems appropriate to determine the factors that have the most significant effect on unrecovered loan. Based on the objectives of the study, the dependent variable is non-performing bank loans in total loans. Independent variables in this study are considered as: bank cash reserves to bank assets ratio, inflation, consumer prices, lending interest rate and GDP.

At first, the initial data were normalized in order to eliminate differences in the indicators measurement units (Table 5, 6).

Then a regression analysis was conducted. The results of determining the regression estimates of the equation for each of the countries are presented in tables 7,8 .

According to the information presented in Table 7, 8: correlation coefficient is 0,8664 for Ukraine and 0,97689152 for India. The correlation coefficients belong to the range $(0.6 ; 0.9)$ therefore linear relationship is sufficient.

Multiple correlation coefficient is 0,7507 (Ukraine) and 0,9543 (India), therefore, a strong correlation is observed between the effective sign and these factor signs. Multiple determination coefficient is only $75,07 \%$ (Ukraine) and 95,43\% (India), of the variance of the effective trait is associated with these factor traits. The value of the Fisher test is 4,5173 (Ukraine) 31,335 (India); number of degrees of Fisher criterion is $k 1=4$ i $k 2=9$, the number of freedom degrees (the Student's criterion) is 9. The calculated value of the Fisher criterion is greater than the critical value and, therefore, the regression equation as a whole is statistically significant and there is good agreement with the observational data. Therefore, the regression model is suitable. 
Table 5. Data standardization for Ukraine

\begin{tabular}{|c|c|c|c|c|c|}
\hline \multirow[b]{2}{*}{ Period } & \multicolumn{5}{|c|}{ Indicator Name } \\
\hline & $\begin{array}{l}\text { Bank unrecovered loans } \\
\text { to total total loans }(\%)\end{array}$ & $\begin{array}{c}\text { Bank cash reserves to bank } \\
\text { assets ratio }(\%)\end{array}$ & $\begin{array}{l}\text { Inflation of consumer } \\
\text { prices (annual \%) }\end{array}$ & $\begin{array}{l}\text { Lending interest } \\
\text { rate }(\%)\end{array}$ & $\begin{array}{l}\text { GDP (mln } \\
\text { US\$ ) }\end{array}$ \\
\hline 2008 & $-1,21$ & $-1,19$ & 0,81 & $-0,32$ & 1,26 \\
\hline 2009 & $-0,62$ & $-0,94$ & 0,11 & 1,39 & $-0,61$ \\
\hline 2010 & $-0,52$ & $-0,47$ & $-0,38$ & $-1,14$ & $-0,04$ \\
\hline 2011 & $-0,55$ & $-0,64$ & $-0,49$ & $-1,10$ & 0,76 \\
\hline 2012 & $-0,44$ & $-0,75$ & $-1,04$ & 0,14 & 1,13 \\
\hline 2013 & $-0,66$ & $-0,23$ & $-1,10$ & $-0,75$ & 1,36 \\
\hline 2014 & $-0,29$ & $-0,66$ & $-0,18$ & $-0,21$ & $-0,17$ \\
\hline 2015 & 0,26 & 1,37 & 2,56 & 1,88 & $-1,40$ \\
\hline 2016 & 0,41 & 1,27 & $-0,04$ & 0,56 & $-1,32$ \\
\hline 2017 & 1,87 & 1,20 & $-0,00$ & $-0,88$ & $-0,76$ \\
\hline 2018 & 1,77 & 1,05 & $-0,26$ & 0,45 & $-0,20$ \\
\hline
\end{tabular}

Source: development of authors

Table 6. Data standardization for India

\begin{tabular}{|c|c|c|c|c|c|}
\hline \multirow{2}{*}{ Period } & \multicolumn{5}{|c|}{ Indicator Name } \\
\cline { 2 - 6 } & $\begin{array}{c}\text { Bank unrecovered loans } \\
\text { to total total loans (\%) }\end{array}$ & $\begin{array}{c}\text { Bank cash reserves to bank } \\
\text { assets ratio (\%) }\end{array}$ & $\begin{array}{c}\text { Inflation of consumer } \\
\text { prices (annual \%) }\end{array}$ & $\begin{array}{c}\text { Lending interest } \\
\text { rate (\%) }\end{array}$ & $\begin{array}{c}\text { GDP (mln } \\
\text { US\$ })\end{array}$ \\
\hline 2008 & $-0,88$ & 2,03 & 0,21 & 2,18 & $-1,59$ \\
\hline 2009 & $-0,88$ & 0,82 & 1,05 & $-1,36$ & $-1,29$ \\
\hline 2010 & $-0,88$ & 0,62 & 1,42 & $-0,12$ & $-0,59$ \\
\hline 2011 & $-0,81$ & 0,00 & 0,38 & 0,19 & $-0,28$ \\
\hline 2012 & $-0,58$ & $-0,35$ & 0,53 & $-0,04$ & $-0,21$ \\
\hline 2013 & $-0,36$ & $-0,99$ & 1,06 & $-0,07$ & 0,17 \\
\hline 2014 & $-0,25$ & $-0,59$ & $-0,45$ & $-0,24$ & 0,31 \\
\hline 2015 & 0,25 & $-0,66$ & $-0,61$ & $-0,49$ & 0,70 \\
\hline 2016 & 1,34 & 1,04 & $-0,92$ & $-0,61$ & 1,46 \\
\hline 2017 & 1,60 & $-0,93$ & $-1,73$ & $-0,94$ & $-0,69$ \\
\hline 2018 & 1,43 & $-0,99$ & $-0,94$ & 1,60 \\
\hline
\end{tabular}

Source: development of authors

Table 7. Regression Summary for Dependent Variable: Bank unrecovered loans to total loans for Ukraine

\begin{tabular}{|c|c|c|c|c|c|c|}
\hline \multirow[t]{2}{*}{$\mathrm{N}=14$} & \multicolumn{6}{|c|}{$\begin{array}{c}\text { Regression Summary for Dependent Variable: Var1 (Spreadsheet1) } \\
\mathrm{R}=0,86644142 \mathrm{R}^{2}=0,75072074 \text { Adjusted } \mathrm{R}^{2}=0,58453457 \\
\mathrm{~F}(4,6)=4,5173 \mathrm{p}<, 05038 \text { Std.Error of estimate: } 0,64457\end{array}$} \\
\hline & $\mathbf{b}^{*}$ & Std. Err. of $b^{*}$ & $\mathbf{b}$ & Std. Err. of b & $\mathrm{t}(9)$ & p-value \\
\hline Intercept & & & 0,000000 & 0,194344 & 0,000000 & 1,000000 \\
\hline $\begin{array}{l}\text { Bank cash reserves to bank } \\
\text { assets ratio (\%) }\end{array}$ & 0,852114 & 0,294866 & 0,852114 & 0,294866 & 2,889832 & 0,027700 \\
\hline $\begin{array}{l}\text { Inflation of consumer prices } \\
\text { (annual \%) }\end{array}$ & $-0,263144$ & 0,274661 & $-0,263144$ & 0,274661 & $-0,958068$ & 0,375025 \\
\hline Lending interest rate $(\%)$ & $-0,081272$ & 0,280435 & $-0,081272$ & 0,280435 & $-0,289808$ & 0,781718 \\
\hline GDP (mln US\$) & $-0,139297$ & 0,345605 & $-0,139297$ & 0,345605 & $-0,403051$ & 0,700880 \\
\hline
\end{tabular}

Source: development of authors 
Table 8. Regression Summary for Dependent Variable: Bank unrecovered loans to total loans for India

\begin{tabular}{|c|c|c|c|c|c|c|}
\hline \multirow[t]{2}{*}{$N=14$} & \multicolumn{6}{|c|}{$\begin{array}{c}\text { Regression Summary for Dependent Variable: Var1 (Spreadsheet1) } \\
\mathrm{R}=0,97689152 \mathrm{R}^{2}=0,95431704 \text { Adjusted } \mathrm{R}^{2}=0,92386174 \\
\mathrm{~F}(4,6)=31,335 \mathrm{p}<0,00037 \text { Std. Error of estimate: } 0,27593\end{array}$} \\
\hline & $\mathbf{b}^{*}$ & Std. Err. of $b^{*}$ & b & Std. Err. of b & $\mathbf{t}(9)$ & p-value \\
\hline Intercept & & & $-0,000000$ & 0,083197 & $-0,000000$ & 1,000000 \\
\hline $\begin{array}{l}\text { Bank cash reserves to bank assets } \\
\text { ratio }(\%)\end{array}$ & 0,404689 & 0,147131 & 0,404689 & 0,147131 & 2,750543 & 0,033268 \\
\hline $\begin{array}{l}\text { Inflation of consumer prices } \\
\text { (annual \%) }\end{array}$ & 0,087744 & 0,248951 & 0,087744 & 0,248951 & 0,352454 & 0,736548 \\
\hline Lending interest rate $(\%)$ & 0,296129 & 0,180540 & 0,296129 & 0,180540 & 1,640247 & 0,152064 \\
\hline GDP (mln US\$ ) & 1,457859 & 0,371780 & 1,457859 & 0,371780 & 3,921295 & 0,007790 \\
\hline
\end{tabular}

Source: development of authors

The column $b$ in the Regression Summary table contains the values of the parameters: $b_{1}=0,852114$, $\mathrm{b}_{2}=-0,263144, \mathrm{~b}_{3}=0,087744, \mathrm{~b}_{4}=-0,139297$ (Ukraine); $b_{1}=0,404689, b_{2}=0,087744, b_{3}=$ $0,296129, b_{4}=1,457859$ (India). To test the significance of the coefficients (b), the observation values of the Student's $t$ test for each coefficient are used. These values are in column $t$ (9) of the Regression Summary table: $t_{\text {observ }}\left(b_{1}\right)=2,889832$, $\mathrm{t}_{\text {observ }}\left(\mathrm{b}_{2}\right)=-0,958068, \mathrm{t}_{\text {observ }}\left(\mathrm{b}_{3}\right)=-0,289808, \mathrm{t}_{\text {observ }}$ $\left(b_{4}\right)=-0,403051$ (Ukraine); $t_{\text {observ }}\left(b_{1}\right)=2,750543$, $\mathrm{t}_{\text {observ }}\left(\mathrm{b}_{2}\right)=0,352454, \mathrm{t}_{\text {observ }}\left(\mathrm{b}_{3}\right)=1,640247, \mathrm{t}_{\text {observ }}$ $\left(b_{4}\right)=3,921295$ (India).

Table 9. Correlation matrix for Ukraine

\begin{tabular}{|l|c|c|c|c|c|}
\hline & $\begin{array}{c}\text { Bank cash reserves } \\
\text { to bank assets ratio }\end{array}$ & $\begin{array}{c}\text { Inflation of } \\
\text { consumer prices }\end{array}$ & $\begin{array}{c}\text { Lending interest } \\
\text { rate }\end{array}$ & GDP & $\begin{array}{c}\text { Bank unrecovered loans } \\
\text { to total total loans }\end{array}$ \\
\hline $\begin{array}{l}\text { Bank cash reserves to } \\
\text { bank assets ratio }\end{array}$ & 1,000000 & 0,375767 & 0,322199 & $-0,714818$ & 0,826604 \\
\hline $\begin{array}{l}\text { Inflation of consumer } \\
\text { prices }\end{array}$ & 0,375767 & 1,000000 & 0,625819 & $-0,551969$ & 0,084363 \\
\hline Lending interest rate & 0,322199 & 0,625819 & 1,000000 & $-0,565735$ & 0,108702 \\
\hline GDP & $-0,714818$ & $-0,551969$ & $-0,565735$ & 1,000000 & $-0,556550$ \\
\hline $\begin{array}{l}\text { Bank unrecovered loans } \\
\text { to total total loans }\end{array}$ & 0,826604 & 0,084363 & 0,108702 & $-0,556550$ & 1,000000 \\
\hline
\end{tabular}

Source: development of authors

On the basis of the data presented in Table 9, a very strong relationship between factor signs bank unrecovered loans to total loans and bank cash reserves to bank assets ratio is observed, since the pair correlation coefficient between them is 0,827 . Between signs lending interest rate and inflation of consumer prices also between GDP and lending interest rate the relationship is moderate. Signs of bank unrecovered loans to total loans and lending interest rate are independent among themselves.
It is appropriate to test the linear model for adequacy using the Fisher test. The critical value of the Fisher criterion with the level of significance $\alpha=$ 0.05 was obtained $F(1,9)=3,249836$. Fisher's observation value $\mathrm{F}_{\text {observ }}=4,5173$ (Ukraine) and $\mathrm{F}_{\text {observ }}=31,335$ (India) greater than the critical value $F(1,9)=3,249836$, then the linear models are adequate.

The next step in the study is to analyze the presence of a pair correlation between the factors attributes included in the regression model, using the correlation matrix (tables 9, 10).
Correlation matrix in table 10 confirms a very strong relationship between factor signs bank unrecovered loans to total loans and GDP, Bank unrecovered loans to total loans and Inflation of consumer prices is observed, since the pair correlation coefficient between them is 0,91 and 0,87 . Between signs lending interest rate and GDP also between Bank cash reserves to bank assets ratio and GDP, inflation of consumer prices and GDP the relationship is moderate. The remaining signs are not characterized by the presence of a significant relationship between each other. 
Table 10. Correlation matrix for India

\begin{tabular}{|l|c|c|c|c|c|}
\hline & $\begin{array}{c}\text { Bank cash reserves to } \\
\text { bank assets ratio }\end{array}$ & $\begin{array}{c}\text { Inflation of } \\
\text { consumer prices }\end{array}$ & $\begin{array}{c}\text { Lending interest } \\
\text { rate }\end{array}$ & GDP & $\begin{array}{c}\text { Bank unrecovered loans } \\
\text { to total total loans }\end{array}$ \\
\hline $\begin{array}{l}\text { Bank cash reserves to } \\
\text { bank assets ratio }\end{array}$ & 1,000000 & 0,318360 & 0,554051 & $-0,685635$ & $-0,402959$ \\
\hline $\begin{array}{l}\text { Inflation of consumer } \\
\text { prices }\end{array}$ & 0,318360 & 1,000000 & 0,212900 & $-0,791725$ & $-0,874889$ \\
\hline Lending interest rate & 0,554051 & 0,212900 & 1,000000 & $-0,676789$ & $-0,448083$ \\
\hline GDP & $-0,685635$ & $-0,791725$ & $-0,676789$ & 1,000000 & 0,910373 \\
\hline $\begin{array}{l}\text { Bank unrecovered loans } \\
\text { to total total loans }\end{array}$ & $-0,402959$ & $-0,874889$ & $-0,448083$ & 0,910373 & 1,000000 \\
\hline
\end{tabular}

Source: development of authors

The graph of the normal probability of the results is presented in Fig. 1, 2.

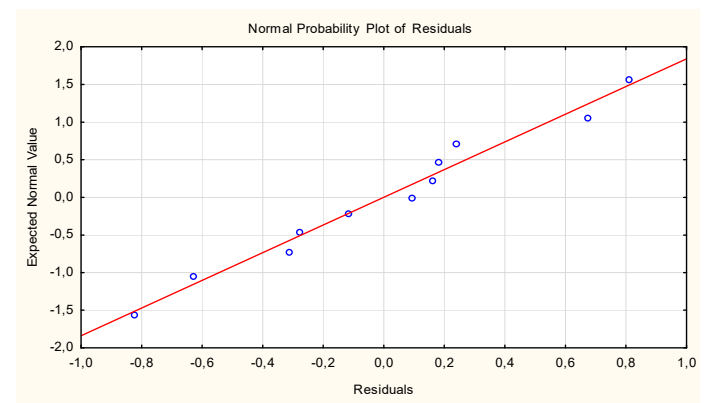

Figure 1. Normal probability plot of results for Ukraine Source: development of authors

The residuals lie well in the straight line, which indicates the adequacy of the model.

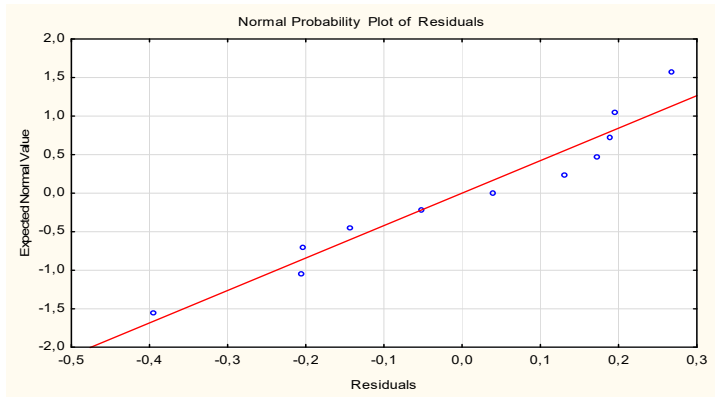

Figure 2. Normal probability plot of results for India Source: development of authors
This results show that the coefficient of inflation, consumer prices, lending interest rate, GDP in the equation where NPL is the dependent variable is negative and statistically significant at the 0,05\% level.

\section{Conclusions}

A comparative analysis of unrecovered loan in Ukraine and India indicates a significantly higher growth rate in Ukraine, which as a result leads to deflation and then to high inflation and an increase in interest rates on loans and, as a result, hinders economic development entrepreneurship. The banking sector in India is characterized by small inflationary fluctuations and lower lending rates, which contributes to the development of the Indian economy.

The main factors affecting bank unrecovered loan for the total amount of loans are: for Ukraine - the ratio of cash reserves to bank assets and GDP; for India - consumer price inflation and GDP. Therefore, when improving a bank management strategy, unrecovered loan should take into account the influence of these factors. 


\section{References}

[1]. Altunbas, Y., Liu, M. H., Molyneux, P., \& Seth, R. (2000). Efficiency and risk in Japanese banking. Journal of Banking \& Finance, 24(10), 1605-1628.

[2]. Beck, R., Jakubik, P., \& Piloiu, A. (2013). Nonperforming loans what matters in addition to the economic cycle? Working paper series, no 1515.

[3]. Berger, A. N., \& DeYoung, R. (1997). Problem loans and cost efficiency in commercial banks. Journal of Banking \& Finance, 21(6), 849-870.

[4]. De Bock, R., \& Demyanets, M. A. (2012). Bank asset quality in emerging markets: Determinants and spillovers (No. 12-71). International Monetary Fund.

[5]. İslamoğlu, M. (2015). The effect of macroeconomic variables on non-performing loan ratio of publicly traded banks in Turkey. Transactions on Business and Economics, 12, 10-20.

[6]. Kjosevski, J., \& Petkovski, M. (2017). Nonperforming loans in Baltic States: determinants and macroeconomic effects. Baltic Journal of Economics, 17(1), 25-44.
[7]. Korpaniuk, T. (2017). Accounting of non-performing long-term bank loans in Ukraine. Banks \& bank systems, (12,№ 4 (cont.)), 121-130.

[8]. Mohanty, A. R., Das, B. R., \& Kumar, S. (2018). Determinants of Non-Performing Loans in India: A System GMM Panel Approach. Prajnan, 47(1).

[9]. Nkusu, M. (2011). Nonperforming loans and macrofinancial vulnerabilities in advanced economies. IMF Working Papers, 1-27.

[10]. Mar Molinero, C., Serrano, C., \& Gallizo, J. L. (2002). A Multivariate Study of the EU Economy Via Financial Statements Analysis. Journal of the Royal Statistical Society: Series D (The Statistician), 51(3), 335-354.

[11]. Slav'yuk, R., Shkvarchuk, L., \& Kondrat, I. (2017). Financial market imbalance: reasons and peculiarities of occurrence in Ukraine. Investment management and financial innovations, (14,№ 1 (contin.)), 227235.

[12]. World Bank. (2020). World Bank Open Data. Retrieved from: https://data.worldbank.org [accessed: 11 May 2020]. 